\title{
Substantiation of innovative aspects of the use of recreational resources in tourism in the context of sustainable development
}

\author{
Olena Lazarieva ${ }^{1, *}$, Svitlana Smyrnova ${ }^{1}$, Andriy Mas ${ }^{1}$, Dmitro Sterlev ${ }^{1}$, and Vasil Koval ${ }^{1}$ \\ ${ }^{1}$ Petro Mohyla Black Sea National University, Department of Land Resources Management, 10, 68- \\ Desantnykiv Steet, 54003 Mykolaiv, Ukraine
}

\begin{abstract}
The mechanism of recreational areas management is improved in this article based on the sustainable development, which means the interaction of components that in their dialectical unity provide a synergistic effect of their rational use and protection. The purpose of article is to generalize and develop scientific and methodological bases and practical recommendations for substantiating the innovative aspects of the use of recreational resources in the context of sustainable development. Sustainable use of lands of recreational potential is focused on the following components of the mechanism, including legislative and regulatory support, mapping of territories, land management, maintaining the state cadaster of territories and objects of recreational use. Using the main approaches to the concept of sustainable development in practice is aimed at determining the effectiveness of recreational activities. Attention is focused on the method of determining the main economic indicators of the use of recreational areas. It is determined that the main components of the land management project are territorial planning of recreational areas, organization of recreational areas, system of measures for protection and restoration of recreational resources and project effectiveness.
\end{abstract}

\section{Introduction}

The main point of the Sustainable development concept was proclaimed at the UN World Conference on the Environment in Rio de Janeiro in 1992, and it is the harmonious combination of building a healthy economy and preserving the environment for future generations, taking into account the long-term environmental consequences from the economic decisions made today, the inclusion of the goal of environmental protection and environmental safety in the policy and practice of socio-economic development.

Within the framework of sustainable development of society, an important place belongs to the formation and use of recreational resources as a condition for maintaining the health of the population and prolonging its life. The policy of sustainable development of territories in Ukraine is defined by the Resolution of the Verkhovna Rada of Ukraine "On the concept of sustainable development of settlements" dated 24.12.1999 №1359-XI

\footnotetext{
*Corresponding author: lazareva95@ukr.net
} 
[1] and received further development within the Comprehensive program of national implementation of decisions taken at the World Summit on sustainable development for 2003-2015 [2]. The strategic goals of long-term development of Ukraine are defined by the framework document Strategy of Sustainable Development of Ukraine until 2030 [3]. The theory and practice of recreational land management are reflected in the works of such famous scientists as I. Burlakova [4], A. Martyn [5], L. Firman [6], Yu. Bondarenko [7], A. Romanova [8], M. Ivanchenko [9], O. Shulat [10], T Pimonenko. [11], K. Kostetska [12], Y. Bilan [13], I. Mikhno [14].

But, despite the significant achievements of scientific research today, the issue of organizing innovative opportunities for the use of recreational resources is insufficiently studied both in theoretical and methodological and practical terms. Currently, there is no management mechanism that would ensure the sustainable development of recreational land use. That is why the need to study and form a recreational policy for the management of recreational land use, in order to ensure its sustainable development, determines the timeliness and relevance of research.

The purpose of the study is to generalize and develop scientific and methodological bases and practical recommendations for substantiating the innovative aspects of the use of recreational resources in the context of sustainable development. Achieving the goal of the study necessitated the solution of the following tasks: to improve the mechanism of management of recreational areas in order to increase the environmental, economic and social efficiency of their use; substantiate the approach to determining the effectiveness of recreational and tourist activities; substantiation of the project of land management of recreational territories.

\section{Methods}

The theoretical and methodological basis of the study were the works of leading scientists on the use of land resources on a sustainable basis. The paper uses such research methods as analysis and synthesis - for the theoretical generalization of modern research on the justification of the components of the mechanism of management of recreational areas; economic analysis - to analyze empirical data and identify trends in land use in the context of sustainable development; graphic - for visual results of scientific research; abstract-logical for theoretical generalization and formation of conclusions.

\section{Results and discussion}

The development of recreational and tourist activities today is one of the priority areas of national culture and economy and creates favorable conditions for tourism.

In our opinion, important components of the mechanism of management of recreational areas are: legislative and regulatory support; mapping of territories; land management; maintaining the state cadastre of territories and objects of recreational use; protection of territories and objects of recreational use and control over observance of their mode; economic regulation of the organization and functioning of recreational areas; standardization and standardization in the field of use of recreational areas; acquisition and realization of the right to land; ensuring the guarantee of the right to land; liability for violation of applicable law; conducting broad international cooperation in this field; development of a system of training, retraining and advanced training of specialists for work in the field of recreational activities. Thus, in the system of management of recreational resources the main legislative acts that determine the main direction of land relations in Ukraine are the Land Code of Ukraine, Water and Forest Codes, laws of Ukraine "On land fees", "On land ownership", "On Entrepreneurship" and many others. 
Only the absence of a deficit of legal and methodological support is the basis for the effective development of recreational areas.

Such a component as mapping is necessary for the production of planning and cartographic material that would reflect all the characteristics of the territory (spatial location of the object, its area, land composition). To perform cadastral surveys today, it is necessary to use GPS systems, which opens up new opportunities for rapid and efficient surveys of large areas.

As for land management, today it is important to organize recreational lands. Nowadays, this is important because until recently, no one really dealt with land management issues in these lands, as a result of which it is impossible to consistently implement scientific methods of their protection and use. It is important to note that the land management project is not only a project of territories organization, but also an organizational and economic plan of territories development, a business plan of development of the territory. It comprehensively addresses the prospects for the development of recreational areas. Note that the land management project should be considered in the following sequence: program - scheme - project - working project. The essence of the land management project in the management system of recreational areas is to make project decisions, their legal, socio-economic, environmental support and practical development of a particular area. The study of such a component of our proposed mechanism for the management of recreational areas as a state cadastre of territories shows that today it is a very problematic matter, as very often recreational areas are created from the lands of primary owners (users) without their withdrawal, so, for example, the park has no authority to carry out cadastral works. In fact, primary users, as experience has shown [15], are not interested in maintaining the state cadaster of entities to which land plots have been transferred without seizure, so as not to combine "incompatible". This means that in cases of new interests of the primary owner or user of the land, he may declare that from the relevant time the land ceases to have the status of recreational areas.

Today, GPS systems are methodologically used to perform cadastral surveys to a greater extent, which opens up new opportunities for rapid and efficient surveys of large areas, especially in cases where sounding materials for these areas are not available.

Control in the system of the State Geocadastre is entrusted to the State Inspectorate for Control over the Use and Protection of Land and its territorial bodies. The State Soil Fertility Protection Service monitors the condition of soils in the system of the central executive body for agricultural policy. It should be noted that the Cabinet of Ministers of Ukraine by order of January 5, 2021 № 6-r transferred the state institution "Institute of Soil Protection of Ukraine" to the management of the State Geocadastre [11].

Economic regulation of the organization and functioning of recreational areas is reflected in financing, tax benefits, environmental insurance, economic incentives, compensation for damages adequate to the land damage, collection of taxes and rent for land use. It should be noted that today the lack of economic and planning zoning is the reason that the investor does not see the benefits of doing business in the periphery of a particular segment of the tourism business market. The presence of such zoning is a "business card" of the land plot, with the help of which the investor has information about the land valuation, possible direction of development of the territory, etc. And if the investor may be given a high price of land in the central places of large crowds of tourists, he can get land at a lower price, but if the vacationers quantity is less.

An important place have also standardization and rationing in the recreational areas management system. Standards and norms are a document that sets out the parameters for the use of recreational areas that ensure the protection of the environment and the health of vacationers. During the development of the methodology of management of recreational areas, it became clear that the process of activating investments for the development of 
recreational business is largely determined by the form of ownership of land intended for recreation. Our research has shown that land ownership has a significant impact on the development of recreational areas, the development of their infrastructure, which is the basis for the establishment of socio-political and socio-economic transformations in the region.

However, the implementation of ownership of recreational areas is complicated because the protected areas of areas within which recreational areas are formed are not confiscated from the private owner, but only given to him for use by administrations, such as landscape regional parks [16]. Therefore, it is no coincidence that lands that can be used as recreational areas are now unclaimed by investors due to the legal unregulated relations between the participants in this process. Liability for violation of current legislation on the use of recreational areas involves a set of management decisions aimed at bringing to civil, administrative or criminal liability.

It should be noted that the success of the policy of effective use of recreational areas is largely determined by the depth of international cooperation in the field of protection and use of areas and objects of nature reserves on the basis of bilateral and multilateral international agreements. A deeper answer to this question is given by Article 66 of the Law of Ukraine "On the Nature Reserve Fund of Ukraine", which declares that international cooperation allows to develop and implement international scientific and scientific-technical programs, create reserves, national parks and other territories. nature reserve fund, to carry out joint training of scientists and specialists, ecological-educational and publishing activities. Therefore, the need to achieve broad international cooperation is of considerable interest in the management system of recreational areas.

In the context of the importance of recreational resources in conditions of sustainability, it is necessary to provide training, retraining and advanced training of specialists for work in the field of recreational activities, as currently the training of such specialists in higher education is not enough [17]. The previously noted parts of mechanism of recreational areas management based on the sustainable developmentt are shown in Fig. 1.

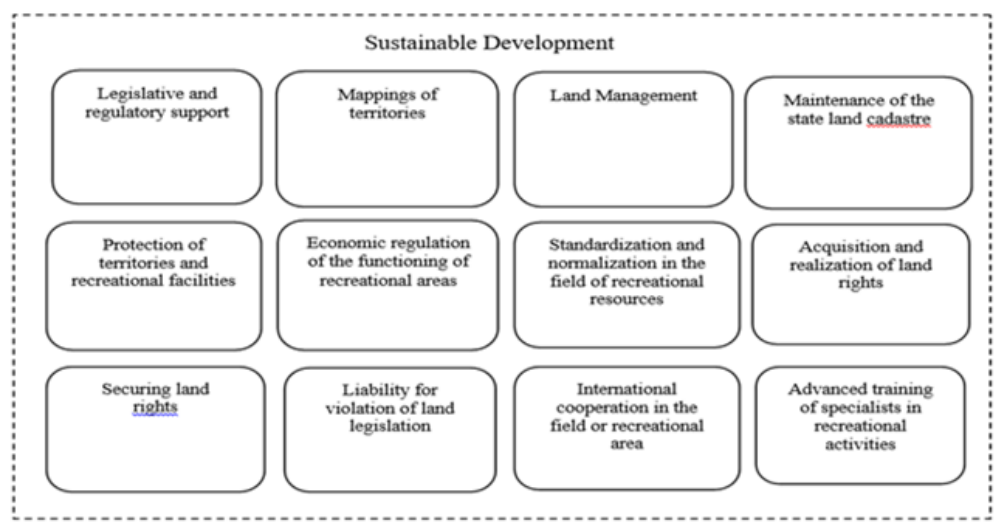

Fig. 1. Mechanism of recreational areas management based on the sustainable development.

All the above components of the mechanism of recreational areas management based on the sustainable development on the basis of the emergence of links create a single comprehensive strategy with a synergistic effect. It should be noted that local residents have a significant impact on recreational resources. Irregular grazing and haymaking have led to the destruction of grass cover and the loss of attractiveness of landscapes. Agricultural production, which is accompanied by the application of mineral and organic 
fertilizers, is the cause of environmental pollution by such toxic heavy metals as lead, cadmium, zinc, copper, nickel [18]. Horizontal water migration redistributes these elements from the soil surface into various runoff, rivers, lakes, waters, etc., which is especially harmful to living organisms. It should be noted that the locals do not incur the full costs of harming the environment when providing tourist services (hiring holidaymakers) and receiving income for it. This means that the public costs of providing tourist services are higher than the costs of individual landlords (Fig 2).

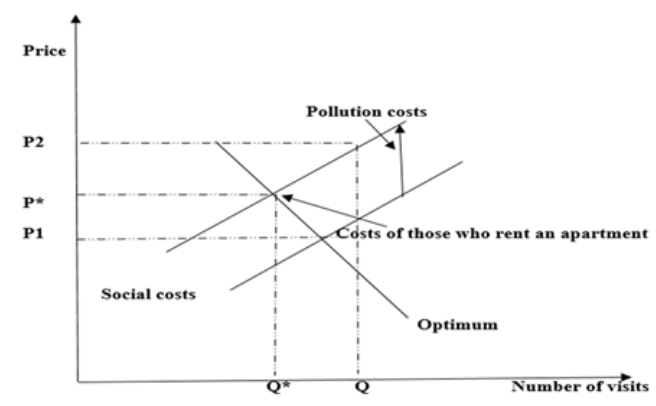

Fig. 2. Socio-ecological optimum of recreational areas visiting.

According to Fig. 2 the price of tourist services provided by landlords is significantly understated, resulting in increasing demand for services. In addition, each subsequent vacationer will rest in a worse natural environment than the previous one, which will eventually come to a point where the state of the natural environment will deteriorate so much that it will lose its appeal. Raising the price for the use of recreational resources to the optimal level, regardless of which entities they will provide - locals with appropriate control over the amount of services provided or hotel services, will initiate a reduction in anthropogenic pressure on the ecosystem. It should be noted that both each business entity and recreational entities try to ensure high efficiency of this type of business in the form of profit in order to invest part of it in the further development of the recreational industry.

Next, we pay attention to the substantiation of the method of determining the main economic indicators of the use of recreational resources, which is based on the subtraction of such indicators as the payback period, the break-even point. Note that the total amount of investment on each of the routes is determined by the formula:

$$
K=\sum_{i=1}^{n} K_{i},
$$

where $K_{i}$ - capital investment by the i-th type of equipment; $i$ - type of equipment; $n-$ types of equipment quantity.

Capital investment by the i-th type of equipment is determined by the formula:

$$
K_{i}=k_{i} Z_{i}
$$

where $k_{i}$ - the number of units of a certain type of equipment of each of the routes; $Z_{i}-$ the price of a certain type of equipment.

To determine the payback period, it is important to take into account the relatively fixed costs, which are determined by the formula:

$$
V_{\text {post }}=\sum_{i=1}^{n} V_{i}
$$


where $V_{i}$ - amount of the i-th type of fixed expenses; $i$-type of expenses; $n$-types of expense quantity. An integral part of determining the payback period is the conditional variable expenses $\left(V_{z \min }\right)$ for each tourists groups, which are defined as the amount of payment to the guide for services; expenses for consumables for one group of tourists (tourists); value added tax. Speaking of break-even point, which reflects the state of the business entity, in which there is no profit, but no losses and is determined by the formula:

$$
T B=\frac{V_{p o s t}}{D-V_{z \min }}
$$

where $V_{\text {post }}$ - amount of fixed expenses during the 1year; $V_{z m i n}-$ the amount of variable expenses per tourist group; $D$ - income of the route from one tourist (excursion) group.

One of the indicators of checking the degree of expediency to engage in entrepreneurial activity is the payback period of investments, which is calculated by the formula:

$$
T_{\text {oк }}=\frac{K}{P_{c h}}
$$

where $K$ - amount of investment in all types of equipment; $P_{c h}-$ net profit for the year.

The application of this method of determining the break-even point of tourist routes and their payback periods based on the socio-economic optimum of visiting recreational areas, allows you to obtain the necessary information for planning, pricing and current management decisions. As the socio-economic and cultural development of Ukraine grows, this area of activity will receive the highest priority, at least this trend is observed around the world. Summarizing the above, the structure of the land management project of recreational areas can be represented as follows (Table 1).

\begin{tabular}{|c|c|}
\hline Project components & \begin{tabular}{|c|} 
Elements \\
\end{tabular} \\
\hline $\begin{array}{l}\text { Territorial planning } \\
\text { of recreational areas }\end{array}$ & $\begin{array}{l}\text { - justification of the need for recreational areas; } \\
\text { - location of recreational areas; } \\
\text { - establishing the boundaries of recreational areas }\end{array}$ \\
\hline $\begin{array}{ll}\text { Recreational } & \text { areas } \\
\text { organization } & \end{array}$ & $\begin{array}{l}\text { Location of inpatient recreation facilities: } \\
\text { - accommodation of hotels; } \\
\text { - location of food outlets; } \\
\text { - placement of shops, kiosks; } \\
\text { - location of the administrative building, production facilities; } \\
\text { - location of water sources. } \\
\text { Location of regulated recreation facilities: } \\
\text { - placement of linear elements of engineering infrastructure; } \\
\text { - placement of small architectural forms (benches for sitting, picnic tables); } \\
\text { - placement of observation decks; } \\
\text { - location of water sources. }\end{array}$ \\
\hline $\begin{array}{l}\text { System of measures } \\
\text { for protection and } \\
\text { restoration of } \\
\text { recreational resources }\end{array}$ & $\begin{array}{l}\text { - biological and restorative measures of fauna and rare plants; } \\
\text { - development of means of protection against the processes of erosion; } \\
\text { - development of measures to protect lands from destruction; } \\
\text { - reclamation of disturbed lands; } \\
\text { - monitoring of recreational resources. }\end{array}$ \\
\hline Project efficiency & $\begin{array}{l}\text { - environmental efficiency; } \\
\text { - social efficiency; } \\
\text { - economic efficiency. }\end{array}$ \\
\hline
\end{tabular}

Table 1. Structure of the land management project of recreational areas.

Land management projects have the task to ensure the attractiveness of recreational areas, their high socio-economic and environmental efficiency. 


\section{Conclusions}

Thus, in the process of research an innovative approach to the formation of the mechanism of use of recreational resources on the basis of sustainable development is formed, which involves the interaction of components that in their dialectical unity provide a synergistic effect of their rational use and protection.

The main components of the mechanism of management of recreational areas are legislative and regulatory support, mapping of territories, land management, maintenance of the state cadastre of territories and objects of recreational use; control over compliance with the regime of use, economic regulation of rational use and protection of territories, standardization and regulation in the field of use and protection of recreational areas, acquisition and implementation of land ownership, guarantees of land rights, liability for violations of current legislation, broad international cooperation in the field protection and use of recreational areas, training system for work in the field of recreational activities.

The approach to recognizing the effectiveness of recreational and tourist activities should be based on the calculation of such indicators as the payback period and the breakeven point based on the socio-economic optimum of visiting recreational areas, which will create conditions for balanced use of natural resources.

In the course of the research it was determined that the list of the main components of the land management project includes: territorial planning of recreational areas; organization of recreational areas; a system of measures for the protection and restoration of recreational resources and the effectiveness of the project, which are important factors and a catalyst for strengthening the role of land management as an effective mechanism for recreational areas managing.

The proposed innovative aspects of the use of recreational resources in the context of sustainable development will promote the intensification of innovation and investment processes, will contribute to the formation of a competitive environment.

Further research should focus on examining the competitive advantages of recreational resources in the context of sustainable development.

\section{References}

1. Verkhovna Rada of Ukraine (1999). About the concept of sustainable development of settlements from 24.12.1999. №1359-XI. https://zakon.rada.gov.ua/laws/show/1359-14\#Text

2. Verkhovna Rada of Ukraine (2003). Comprehensive program for the implementation at the national level of the decisions taken at the World Summit on Sustainable Development for 20032015. https://zakon.rada.gov.ua/laws/show/634-2003-\%D0\%BF\#Text

3. President of Ukraine (2019). Strategy of sustainable development of Ukraine until 2030. https://zakon.rada.gov.ua/laws/show/722/2019?lang=en\#Text

4. Burlakova, I., Sheviakov, O., \& Kondes, T. (2020). Features of corporate well-being. Corporate Management: from Creation to Success: monograph. Tallin: Scientific Center of Innovative Researches OU: "Krok" University: Academy of Economics and Pedagogy. p. 145-154.

5. Martyn, A., Kubakh, S. (2018). Land survey and land evaluation in Ukraine: time for systematic deregulation. Land management Bulletin, 10, 24-29.

6. Firman, L. Yu., Klimenko, \& Kh. O. (2019). Tourism in Ukraine: realities and prospects. Proceeding 1st International Scientific and Practical Conference "Ecological safety of objects of tourists of tourist-recreational complex". Lviv: LDUBJD (p. 61-63).

7. Bondarenko, Yu. H., \& Kulinich, T. V. (2018). Investigation of conditions and benefits for Ukraine in the transition of its household in the rank of the internal investor of the state EUREKA: Social and Humanities. Tallinn, Eesti, European Union: Publisher OÜ "Scientific Route", 1(13), 10-22.

8. Romanova, A. (2017). Global trends of tourism development. Herald of KNUTE, 6, 32-41. 
9. Ivanchenko, M. (2015). Problems and prospects for the development of recreational tourism. Efektivna economika, 5. http://www.economy.nayka.com.ua/?op=1\&z=4112

10. Shulat, O. (2015). Formation of the concept of "tourism" in modern economic science. Efektivna economika, 12. http://www.economy.nayka.com.ua/?op=1\&z=4659

11. Pimonenko, T., Prokopenko, O., \& Dado, J. (2017). Net zero house: EU experience in Ukrainian conditions. International Journal of Ecological Economics and Statistics, 38(4), 46-57.

12. Kostetska, K., Khumarova, N., Umanska, Y., Shmygol, N., \& Koval, V. (2020). Institutional qualities of inclusive environmental management in sustainable economic development. Management Systems in Production Engineering, 28 (2), 15-22. https://doi.org/10.2478/mspe2020-0003

13. Bilan, Y., Zos-Kior, M., Nitsenko, V., Sinelnikau, U., \& Ilin, V. (2017). Social component in sustainable management of land resources. Journal of Security and Sustainability, 7(2), 107-120.

14. Mikhno, I., Koval, V., Shvets, G., Garmatiuk, O., \& Tamošiūnienè, R. (2021). Green Economy in Sustainable Development and Improvement of Resource Efficiency. Central European Business Review, 10(1), 99-113.

15. Cabinet of Minister of Ukraine (2021). On the transfer of the entire property complex of the state institution. Institute of Soil Protection of Ukraine "to the management of the State Service for Geodesy, Cartography and Cadastre. https://www.kmu.gov.ua/npas/pro-peredachu-cilisnogomajnovogo-a6r

16. Ivanov, E., Loboichenko, V., Artemev \& S., Vasyukov, A. (2016). Emergency situations with explosions of ammunition: Patterns of occurrence and progress. EasternEuropean Journal of Enterprise Technologies, 1 (10), 26-35.

17. Maksymiv, L., Garmatiy, T., Betz, M. (2020). Socio-ecological and economic aspects of the ecological tourism development in the Ukrainian. Proceedings of the forestry academy of sciences of Ukraine, 20, 149-161.

18. Andryeyeva, O., Blagiy, O. (2015). The system of training and qualification improvement of specialists in physical recreation. Physical education, sports and health culture in modern society: a collection of scientific papers, 3 (31), 5-10. 